\title{
Mesenchymal stem cells protect against acetaminophen hepatotoxicity by secreting regenerative cytokine hepatocyte growth factor
}

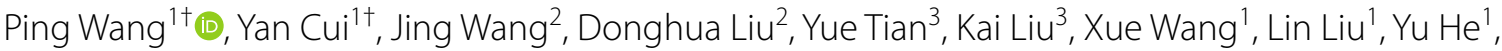 \\ Yufeng Pei ${ }^{1}$, Li Li ${ }^{1}$, Liying Sun ${ }^{4}$, Zhijun Zhu ${ }^{4}$, Dehua Chang ${ }^{5^{*}}$, Jidong Jia ${ }^{1,3^{*}}$ and Hong You ${ }^{1,3^{*}}$
}

\begin{abstract}
Background: Acetaminophen (APAP) overdose is a major cause of the morbidity of acute liver failure. The current clinically approved treatment for APAP poisoning, $\mathrm{N}$-acetylcysteine (NAC), has a limited therapeutic window, and prolonged treatment with NAC delays liver regeneration. Mesenchymal stem cells (MSCs) also have therapeutic effects on APAP-induced mouse liver failure, but whether the effects are comparable to those of NAC has not been determined, and the mechanism still needs further exploration.

Methods: Fasted C57BL/6 mice that received $500 \mathrm{mg} / \mathrm{kg}$ APAP were treated intravenously with $300 \mathrm{mg} / \mathrm{kg}$ NAC or different amounts of MSCs at $2 \mathrm{~h}$ after APAP to investigate survival, hepatocyte necrosis and neutrophil/macrophage recruitment. In vitro co-culture was performed to study the anti-necrotic effects of MSCs on the APAP-injured hepatocyte cell line L-O2.

Results: MSCs dose-dependently rescued the C57BL/6J mice from APAP-induced liver failure, with 87.5\% of MSCs $\left(1 \times 10^{6}\right)$ surviving similar to that of NAC (90\%). MSC has similar effects on reduced hepatocyte necrosis and granulocytic myeloid-derived suppressor cells (MDSC) infiltration but enhanced the proportion of regenerative monocytic MDSC when compared to NAC. Mechanistically, MSCs attenuate hepatocyte necrosis by secreting hepatocyte growth factor (HGF). When HGF was knocked down, the protective effects of MSCs were reduced on APAP-induced hepatocyte necrosis and mouse liver failure.
\end{abstract}

Conclusions: MSCs are comparable to NAC against APAP-induced liver failure by secreting HGF with less regenerative retardation concerns, thus facilitating the application of MSCs in clinical therapy for APAP liver failure.

Keywords: Mesenchymal stem cells, Acetaminophen, N-acetylcysteine, Hepatocyte growth factor

*Correspondence: dehua_chang@yahoo.com; jia_jd@ccmu.edu.cn; youhongliver@ccmu.edu.cn

${ }^{\dagger}$ Ping Wang and Yan Cui contributed equally to this work

${ }^{1}$ Liver Research Center, Beijing Friendship Hospital, Capital Medical University, Beijing Key Laboratory of Translational Medicine on Liver Cirrhosis and National Clinical Research Center for Digestive Diseases, No. 95 Yong-An Road, Beijing 100050, China

${ }^{5}$ Department of Cell Therapy in Regenerative Medicine, University of Tokyo Hospital, Tokyo 113-8655, Japan

Full list of author information is available at the end of the article

\section{Background}

As the most widely used non-prescription analgesic/ antipyretic, an overdose of paracetamol (acetaminophen, APAP) can be taken in either deliberately or unintentionally, resulting in acute liver injury and even liver failure. APAP overdose accounts for almost $50 \%$ of all deaths from acute liver failure in the USA, the UK and many other Western countries [1-5]. There are several clinical original author(s) and the source, provide a link to the Creative Commons licence, and indicate if changes were made. The images or other third party material in this article are included in the article's Creative Commons licence, unless indicated otherwise in a credit line to the material. If material is not included in the article's Creative Commons licence and your intended use is not permitted by statutory regulation or exceeds the permitted use, you will need to obtain permission directly from the copyright holder. To view a copy of this licence, visit http://creativecommons.org/licenses/by/4.0/. The Creative Commons Public Domain Dedication waiver (http://creativeco mmons.org/publicdomain/zero/1.0/) applies to the data made available in this article, unless otherwise stated in a credit line to the data. 
interventions for APAP overdose poisoning, including blocking its absorption by the gastrointestinal tract (activated charcoal to bind APAP, gastric lavage to wash out APAP and ipecacuanha to cause vomiting), removing APAP from the vascular system (using blood filtration equipment) and preventing the formation of toxic metabolites [methionine, cysteamine, dimercaprol or $\mathrm{N}$-acetylcysteine (NAC)]. Among the antidotes that may reduce the amount of toxic products, the administration of NAC has been shown to be a safe and effective therapy to improve the survival rate of APAP-induced fulminant hepatic failure in many clinical controlled trials $[6,7]$. Until now, NAC has been the only clinically approved antidote recommended and is the most beneficial therapy for APAP overdose patients at risk of liver damage $[8,9]$. However, a systematic review of published randomized clinical trials showed that the grade of the evidence quality for NAC is low [10], which may be due to the limited therapeutic window of NAC $[11,12]$, and prolonged NAC treatment delays liver regeneration by inducing hepatocyte vacuolation [13]. Furthermore, some side effects, including nausea and vomiting, have been reported after either oral or intravenous NAC administration [14-16]. Therefore, there is still an urgent need to develop new therapeutic options for APAP overdose poisoning.

At safe doses, most APAP (90-95\%) is metabolized by glucuronosyltransferase or phenolsulfotransferases into non-toxic compounds and removed from hepatocytes by excretion into bile or plasma [17]. Only $5-10 \%$ of APAP is metabolized by the hepatocyte cytochrome $\mathrm{P} 450$ enzyme Cyp2E1 to generate the reactive and toxic metabolite $N$-acetyl-p-benzoquinone imine (NAPQI), which can be detoxified by glutathione (GSH) [17]. APAP overdose leads to GSH depletion and excessive production of NAPQI, which binds to the cysteine residues of proteins to trigger mitochondrial dysfunction and nuclear DNA fragmentation [18], thus resulting in the necrosis of hepatocytes and failure of liver function [16, 19]. As a GSH precursor, NAC can replenish GSH levels to reduce the covalent binding of NAPQI to proteins and scavenge ROS to maintain mitochondrial energy metabolism to restrict hepatocyte necrosis and liver inflammation $[17,20]$.

Mesenchymal stem cells (MSCs) isolated from bone marrow, adipose tissue, umbilical cord, etc. have demonstrated safety and feasibility with anti-apoptosis, anti-fibrosis and immune modulation effects for many acute and chronic liver diseases [21]. Both human and mouse MSCs have been found to significantly improve the mouse survival rate for APAP-induced fulminant liver failure [22-26], suggesting that the administration of MSCs may be another therapeutic option for APAP poisoning [26]. It has also been revealed that MSCs can inhibit CYP2E1 activity [25], maintain GSH levels [27] and increase antioxidant enzyme activity [28] in APAPinjured rodent livers to reduce hepatocyte necrosis. However, whether the effects of MSCs are comparable to those of NAC has not been considered, and the key cytokines responsible for the therapeutic effects of MSCs have not been revealed. To address this question, we compared the effects of MSCs to NAC on APAP-induced fulminant liver failure and identified the cytokines secreted by MSCs to protect hepatocytes from APAPinduced necrosis, thus providing a preclinical study on the usefulness of MSCs for treating APAP hepatotoxicity.

\section{Methods}

\section{Isolation and in vitro culture of MSCs}

Healthy pregnant volunteer with no detectable virus infection and no family history of genetic diseases were recruited to this study to donate umbilical cords after childbirth with written informed consent for the GRIPP2 guidelines. This cell-obtaining project was approved by the Ethical Committees of ASIS Hospital Beijing, China (No. LLPJ2017[001]). For mesenchymal stem cell isolation, Wharton's jelly was isolated, cut into small pieces and digested by collagenase (Sigma-Aldrich, St. Louis, MO, USA). After filtration through $80-\mathrm{mm}$ filter, the cell suspension was centrifuged at $1500 \mathrm{rpm}$ for $5 \mathrm{~min}$ to obtain the cells. The cells were cultured and expanded in aMEM (Corning, Manassas, VA, USA) supplemented with $10 \%$ foetal bovine serum (Gibco, Auckland, New Zealand) and bFGF (Nanhai Longtime Pharmaceutical, Foshan, China) at $37^{\circ} \mathrm{C}$ with $5 \% \mathrm{CO}_{2}$.

\section{Flow cytometry for MSC analysis}

MSCs were prepared and analysed by surface or intracellular antigen staining according to standard protocols, as described previously [29] using the primary antibodies to detect surface antigens of CD105 (BioLegend, San Diego, CA, USA), CD44 (BioLegend), CD90 (BioLegend), CD73 (BioLegend), CD34 (BioLegend), CD45 (BioLegend) or HLA-DR (BioLegend) and intracellular antigens of HGF (Sigma-Aldrich), EGF (Sigma-Aldrich) or IL-6 (BioLegend). Cell fluorescence was analysed with a FACSAria II (BD Biosciences) using CellQuest software (BD Bioscience).

\section{Acute liver injury and cell transplantation}

Male C57BL/6 J mice with a body weight (B.W.) of $22.0 \pm 2.0 \mathrm{~g}$ were purchased from Beijing HFK Bioscience Co. (Beijing, China) and maintained under pathogen-free conditions with free access to standard pelleted chow and water. The experimental protocol was approved by the Animal Care and Use Committee of Beijing Friendship Hospital, Capital Medical 
University (No. 19-2010). The mice were fasted overnight and intraperitoneally administered $0 \quad(N=4)$, $400(N=7), 500(N=7)$ or $600 \mathrm{mg} / \mathrm{kg}$ B.W. $(N=7)$ APAP dissolved in warm saline $(15 \mathrm{mg} / \mathrm{ml})$ to optimize the APAP dose, and mouse survival was observed for 7 days [25]. For NAC dose optimization [20], the fasted mice were administered $0(N=11), 200(N=8)$, $300(N=11)$ or $400 \mathrm{mg} / \mathrm{kg}$ B.W. $(N=10)$ NAC intravenously through the tail vein at $2 \mathrm{~h}$ after $500 \mathrm{mg} / \mathrm{kg}$ B.W. APAP injection, and mouse survival was observed for 7 days. For survival analysis of MSC treatment, the fasted mice received PBS $(100 \mathrm{ml})(N=8)$ as a negative control, $300 \mathrm{mg} / \mathrm{kg}$ B.W. NAC $(100 \mathrm{ml})(N=10)$ as positive control or $5 \times 10^{5}(100 \mathrm{ml}, N=8), 1 \times 10^{6}$ $(100 \mathrm{ml}, N=9), 1.5 \times 10^{6}(100 \mathrm{ml}, N=13), 2 \times 10^{6}$ $(100 \mathrm{ml}, N=14)$ MSCs intravenously through tail vein $2 \mathrm{~h}$ after $500 \mathrm{mg} / \mathrm{kg}$ B.W. APAP injection. Serum from the tail vein of the surviving mice was collected at $24 \mathrm{~h}$ post-APAP administration, and mouse survival was observed for 7 days. For tissue analysis and serum NAPQI analysis after MSC treatment, the fasted mice received PBS (100 ml, $N=11), 300 \mathrm{mg} / \mathrm{kg}$ B.W. NAC $(100 \mathrm{ml}, N=6)$ or $1.5 \times 10^{6} \mathrm{MSCs}(100 \mathrm{ml}, N=9)$ intravenously through the tail vein $2 \mathrm{~h}$ after $500 \mathrm{mg} / \mathrm{kg} \mathrm{B.W}$. APAP injection, and the tissues and serum were collected $24 \mathrm{~h}$ after APAP injection. To analyse the effects of HGF-knockout (HGF ${ }^{\mathrm{ko}}$ ) MSCs, fasted mice received PBS $(100 \mathrm{ml}, N=9), 1.0 \times 10^{6}$ non-specific gRNA control MSCs $(100 \mathrm{ml}, N=8)$ or $1.0 \times 10^{6} \mathrm{HGF}^{\mathrm{ko}} \mathrm{MSCs}$ $(100 \mathrm{ml}, N=8)$ or $50 \mathrm{mg} / \mathrm{kg}$ B.W. mouse HGF $(N=8$, Sino Biological, Beijing, China) or $100 \mathrm{mg} / \mathrm{kg} \mathrm{B.W.}$ mouse HGF $(N=8)$ or $150 \mathrm{mg} / \mathrm{kg}$ B.W. mouse HGF $(N=8) 2 \mathrm{~h}$ after $500 \mathrm{mg} / \mathrm{kg}$ B.W. APAP injection, and mouse survival was observed for 7 days.

\section{Serum NAPQI}

Serum NAPQI levels were analysed by mouse NAPQI ELISA kit according to the manufacturer's instructions (RYBIO, Shanghai, China). Briefly, NAPQI standards $(50 \mathrm{ml})$ and fivefold diluted mouse serum were added to the microelisa strips. Then, HRP-conjugate reagent $(100 \mathrm{ml})$ was added to each well and incubated for $60 \mathrm{~min}$ at $37^{\circ} \mathrm{C}$. After 5 washes by wash solution, chromogen solution A $(50 \mathrm{ml})$ and chromogen solution $\mathrm{B}(50 \mathrm{ml})$ were added to each well and incubated for $15 \mathrm{~min}$ at $37^{\circ} \mathrm{C}$. After adding stop solution $(50 \mathrm{ml})$, absorbance was measured at $450 \mathrm{~nm}$ by microplate reader. The background was corrected by subtracting the final measurement $\left(\mathrm{OD} 450_{\text {final }}\right)$ obtained for the S0 standard from the OD450 final obtained for the standards and samples. Using the corrected measurments,
NAPQI levels were determined according to the standard curve and dilution fold.

\section{Necrosis analysis of APAP-treated L-O2 cells co-cultured with MSCs}

L-O2 cells were plated in 6-well plates at $1 \times 10^{6}$ cells/ well, and MSCs were plated on chambers adapted to fit in 6-well plates at cell numbers of $5 \times 10^{5}, 1 \times 10^{6}$, $1.5 \times 10^{6}$ and $2 \times 10^{6}$ at $37{ }^{\circ} \mathrm{C}$ overnight. Then, the chambers with MSCs were placed on L-O2 cells and cultured in $20 \mathrm{mM}$ APAP at $37{ }^{\circ} \mathrm{C}$ and $5 \% \mathrm{CO}_{2}$ for $18 \mathrm{~h}$. The chambers with MSCs were discarded, and the remaining supernatant and L-O2 cells in each well were collected and stained with a PE Annexin V Apoptosis Detection Kit I according to the manufacturer's instructions (BD Pharmingen, Franklin Lakes, NJ, USA). Briefly, after two washes with cold PBS, the cells were resuspended in $1 \times$ Binding Buffer at a concentration of $1 \times 10^{7}$ cells $/ \mathrm{ml}$. PE-labelled Annexin V antibodies $(1 \mathrm{ml})$ and 7 -AAD $(1 \mathrm{ml})$ were added to $1 \times 10^{6}$ cells and incubated for $15 \mathrm{~min}$ at RT in the dark. After adding $400 \mu \mathrm{l}$ of $1 \times$ binding buffer to each tube, apoptosis/ necrosis was analysed by FACSAria II (BD Biosciences) or FACSCalibur flow cytometry (BD Biosciences) using CellQuest software (BD Biosciences).

\section{Western blotting}

Protein extracts were prepared and analysed by Western blotting according to standard protocols, as described previously [29] using the primary antibodies of HGF (Sigma-Aldrich), EGF (Sigma-Aldrich) and IL-6 (BioLegend). Bands were detected using a Molecular Imager ChemiDoc $\mathrm{XRS}^{+}$with Image Lab Software version 3.0 (Bio-Rad, Hercules, CA, USA).

\section{HGF-knockout MSC preparation}

HGF-knockout MSCs were prepared by a two-step CRISPR-Cas9 system. First, $3 \times 10^{5}$ MSCs per well were plated in a 6-well plate, and the cells were infected with lentivirus containing the Cas 9 gene $(\mathrm{MOI}=10$, SyngenTech, Beijing, China). Four days after infection, the cells were passaged to $60-\mathrm{mm}$ plates and cultured in the presence of blasticidin antibiotic selection at $1.0 \mu \mathrm{g} / \mathrm{mL}$ for 4 days to obtain Cas9-expressing MSCs. Second, $3 \times 10^{5}$ Cas9-expressing MSCs were plated in a 6-well plate, and the cells were infected with lentivirus containing human HGF gRNA (CATCGCCATCCC CTATGCAG) (SyngenTech) or non-specific control gRNA (SyngenTech). Four days after transfection, the cells were passaged to $60-\mathrm{mm}$ plates and cultured in the presence of puromycin antibiotic selection at $1.5 \mu \mathrm{g} / \mathrm{mL}$ for 4 days. The selected cells were expanded in the presence of $0.2 \mu \mathrm{g} / \mathrm{mL}$ puromycin afterwards. 


\section{Transcriptional analysis by RT-PCR}

Cells $\left(2 \times 10^{6}\right)$ were used for total RNA extraction, reverse transcription and real-time quantitative polymerase chain reaction (RT-PCR), which were carried out according to the methods described previously [29]. The primers used for amplification are shown in Table 1, and gene transcription levels were calculated relative to GAPDH levels based on the 2- $\Delta \Delta \mathrm{Ct}$ method [29].

\section{Statistics}

Sample sizes were chosen based on previous similar experimental outcomes. Data are presented as the mean values $\pm S D$ and were analysed for significance using two-tailed Mann-Whitney $U$ test with GraphPad Prism 6 software (GraphPad, La Jolla, CA, USA). $P<0.05$ was indicative of a significant difference.

\section{Results}

MSC transplantation improves the survival of APAP-treated mice, similar to NAC treatment

Human umbilical MSCs obtained by collagenase digestion showed a fibroblast-like morphology under in vitro culture conditions (Fig. 1a). Immunofluorescence staining and FACS analysis of the immunophenotype of these cells revealed that the positivity rates for the haematopoietic cell markers CD34, CD45 and HLA-DR were less than $2 \%$ (Fig. 1b), while the positivity rates for the MSC markers CD105, CD44, CD90 and CD73 were over 99\% (Fig. 1c).

Table 1 Primers designed for specific human genes

\begin{tabular}{llll}
\hline Name & Accession no & Primer sequence $\left(\mathbf{5}^{\prime} \mathbf{-} \mathbf{3}^{\prime}\right)$ & Product $(\mathbf{b p})$ \\
\hline EGF & NM_001963.6 & TGTCCACGCAATGTGTCTGA & 133 \\
& & CATTATCGGGTGAGAACAACC & \\
HGF & NM_000601.6 & GCTATCGGGGTAAGACCTACA & 99 \\
& & CGTAGCGTACCTCTGGATTGC & \\
IL-6 & NM_000600.5 & ACTCACCTCTTCAGAACG & 149 \\
& & AATTG \\
& & CCATCTTTGGAGGTTCA & \\
& & GGTTG \\
GAPDH NM_002046.7 & GGAGCGAGATCCCTCCAAAT & 197 \\
& & GGCTGTTGTCATACTTCTCATGG & \\
\hline
\end{tabular}

Before we investigated the effects of MSCs on mouse survival after APAP challenge, the appropriate APAP dose to induce acute mouse liver failure was determined by the intraperitoneal injection of different doses of APAP (Additional file 1A). As expected, APAP dosedependently induced mouse death with survival proportions for $400 \mathrm{mg} / \mathrm{kg}$ B.W., $500 \mathrm{mg} / \mathrm{kg}$ B.W. and $600 \mathrm{mg} /$ $\mathrm{kg} \mathrm{B.W.} \mathrm{of} 71.4 \%, 28.6 \%$ and $0 \%$, respectively (Additional file 1A). Therefore, $500 \mathrm{mg} / \mathrm{kg}$ B.W. APAP was used in the following experiments to induce mouse liver failure. We also optimized the NAC dose for treating APAP $(500 \mathrm{mg} /$ $\mathrm{kg}$ B.W.)-induced fulminant liver failure with survival proportions for $200 \mathrm{mg} / \mathrm{kg}$ B.W., $300 \mathrm{mg} / \mathrm{kg} \mathrm{B.W}$. and $400 \mathrm{mg} / \mathrm{kg} \mathrm{B.W}$. of $75.0 \%, 83.3 \%$ and $70.0 \%$, respectively (Additional file 1B). Therefore, $300 \mathrm{mg} / \mathrm{kg}$ B.W. NAC was used as the positive control to evaluate the effects of MSCs.

To investigate the therapeutic effects of MSCs on APAP-induced liver failure, different doses of MSCs were administered to APAP (500 mg/ $/ \mathrm{kg} \mathrm{B.W.)-induced}$ liver failure mice (Fig. 1d). At the time of MSC administration, one mouse (1/9) died immediately after the administration of $1.0 \times 10^{6}$ MSCs, 4 mice (4/13) died after the administration of $1.5 \times 10^{6}$ MSCs, and 11 mice (11/14) died after the administration of $2.0 \times 10^{6}$ MSCs due to pulmonary infarction. Among the remaining mice, the survival proportion of mice increased dose-dependently after the administration of $5 \times 10^{5}$ and $1 \times 10^{6}$ MSCs from 50.0 to $87.5 \%$ (Fig. 1 e), while a higher dose of MSCs did not further enhance the survival rate (Fig. 1e). The survival proportion was $87.5 \%$ in mice that received $1 \times 10^{6} \mathrm{MSCs}$ and was similar to the rate of $90.0 \%$ in mice that received NAC (300 mg/kg B.W.) (Fig. 1e). Liver damage was monitored by measuring serum ALT and AST levels at $24 \mathrm{~h}$ after APAP injection and revealed that the administration of MSCs $\left(\geq 1 \times 10^{6}\right)$ significantly reduced ALT levels, and the administration of MSCs $\left(\geq 5 \times 10^{5}\right)$ markedly reduced AST levels (Fig. 1f). Although a higher number of MSCs $\left(\geq 1.5 \times 10^{6}\right)$ did not further enhance the mouse survival proportion, there was a dose-dependent reduction in the serum levels of ALT and AST from the administration of $5 \times 10^{5}-2 \times 10^{6}$ MSCs (Fig. 1f). There was no significant difference between MSC $\left(\geq 1.5 \times 10^{6}\right)$ and NAC $(300 \mathrm{mg} / \mathrm{kg}$ B.W. $)$

\footnotetext{
(See figure on next page.)

Fig. 1 The rescue effects of MSC administration on APAP-induced liver failure are similar to those of NAC. a Morphology of in vitro-cultured MSCs. b Immunostaining and flow cytometry analysis revealed that MSCs did not express the haematopoietic stem cell marks CD34, CD45 and HLA-DR. c Immunostaining and flow cytometry analysis revealed that MSCs expressed CD105, CD44, CD90 and CD73. d Schematic representation of the experimental design to determine the effects of MSCs on APAP-induced liver failure. e Seven-day survival curve after APAP (500 mg/kg B.W.)-induced liver failure mice treated with PBS or MSCs $\left(5 \times 10^{5}, 1 \times 10^{6}, 1.5 \times 10^{6}, 2 \times 10^{6}\right.$ cells) or NAC (300 mg/kg B.W.). f Serum ALT and AST levels at $24 \mathrm{~h}$ after APAP challenge. Data are expressed as the mean $\pm \mathrm{SD}$, and significant differences between groups are shown in red
} 

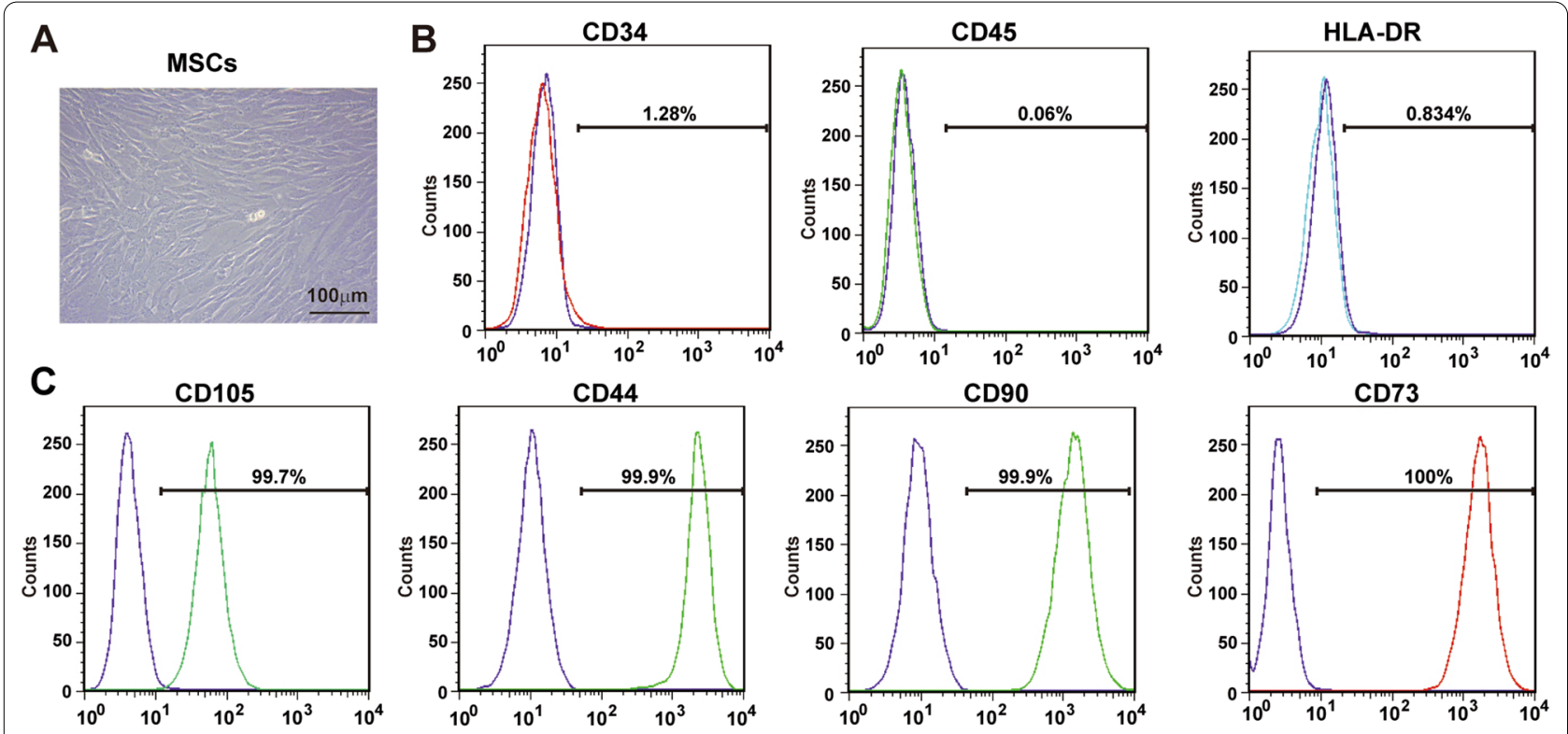

D $500 \mathrm{mg} / \mathrm{kg}$ B.W. MSC transplantation or
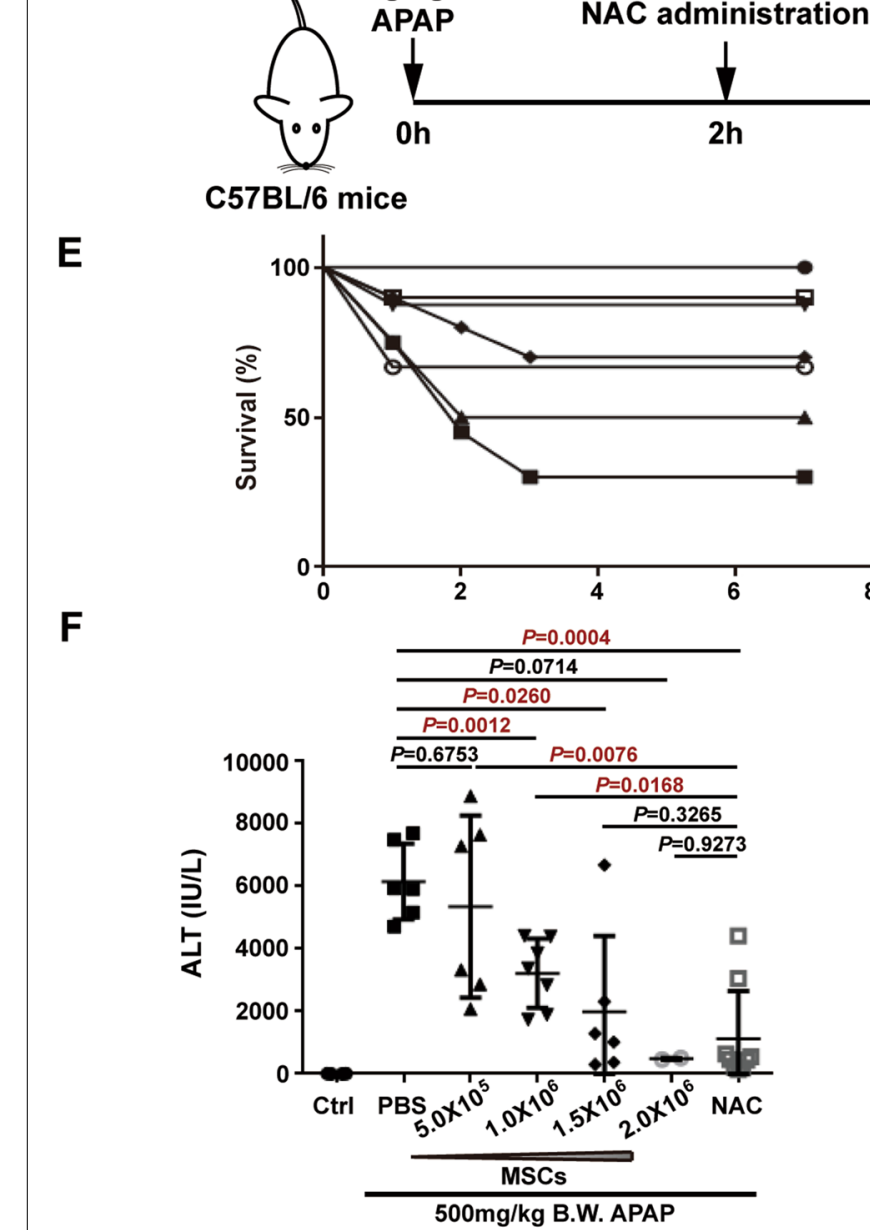

Fig. 1 (See legend on previous page.)

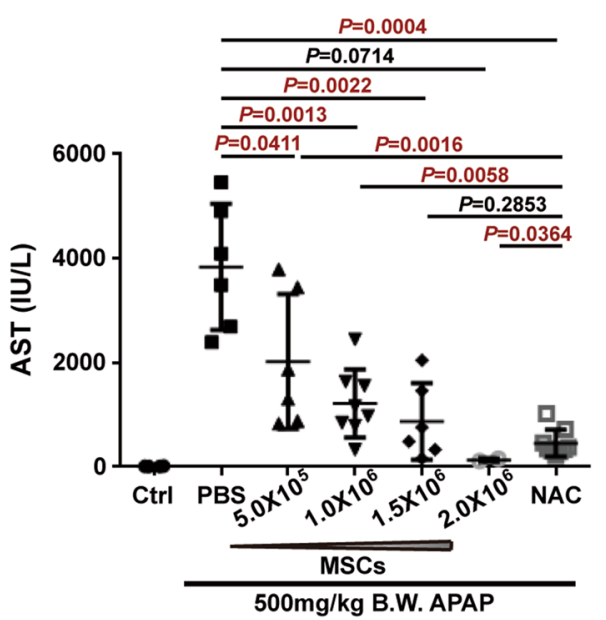


administration on ALT levels, and the AST level was significantly lower in MSC $\left(2.0 \times 10^{6}\right)$ administration than that in NAC administration (Fig. 1f). Therefore, MSC administration improves survival and attenuates liver injury in APAP-induced liver failure, which is comparable to the administration of NAC.

\section{Similar to NAC treatment, MSC administration reduces} the necrosis of hepatocytes after APAP challenge

To examine histological changes, liver tissue was collected, and hepatocyte necrosis was analysed after the administration of MSCs $\left(1.5 \times 10^{6}\right)$ to treat APAPinduced liver failure. Compared to PBS treatment, both MSC and NAC administration reduced liver congestion at $24 \mathrm{~h}$ after APAP administration (Fig. 2a). HE staining
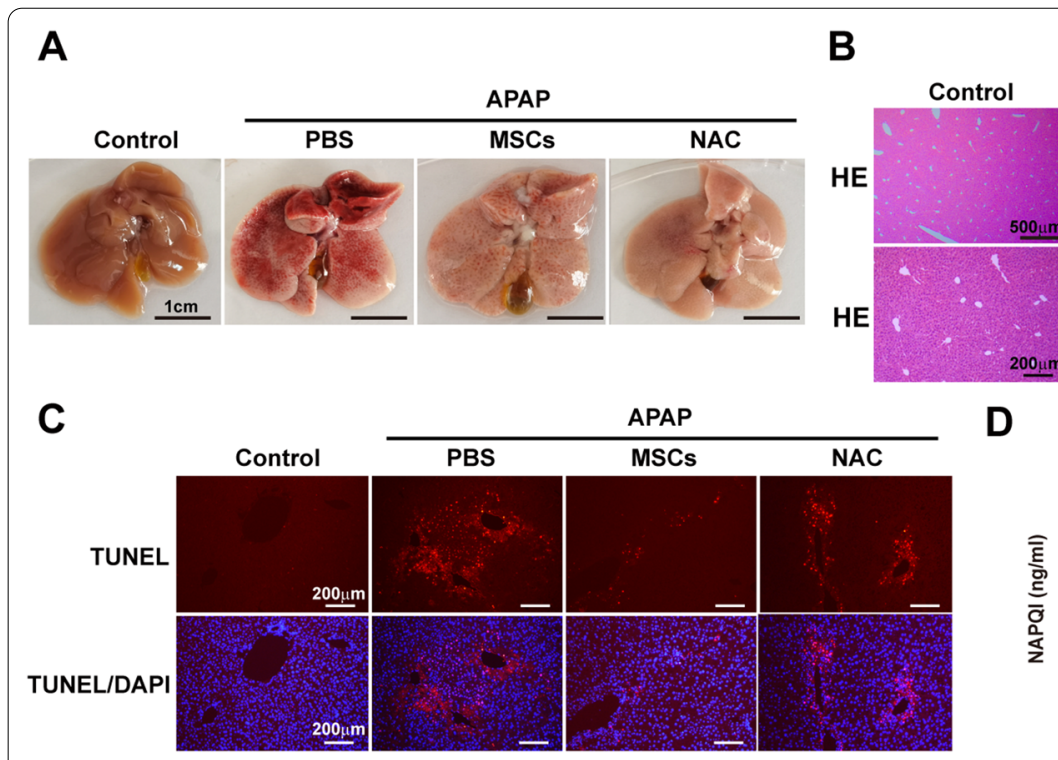

D
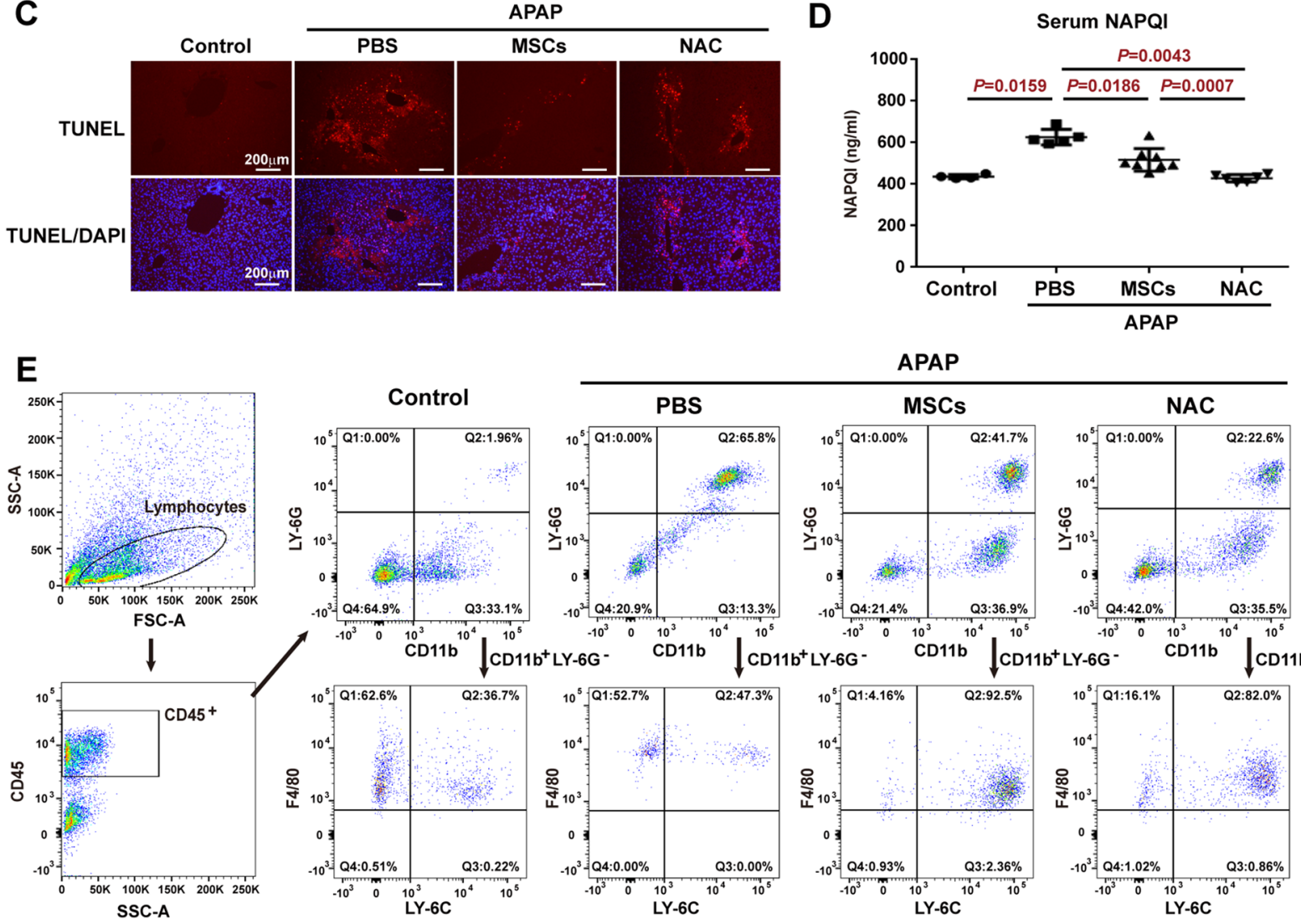

Fig. 2 MSCs attenuate hepatocyte necrosis and liver inflammation induced by APAP in a similar tendency to NAC. a Representative macroscopic view of livers from control mice or APAP mice administered PBS, MSCs $\left(1.5 \times 10^{6}\right)$ or NAC (300 mg/kg B.W.) at 24 h after APAP challenge (500 mg/ kg B.W.). b Representative liver sections with HE staining from control mice or APAP mice administered PBS, MSCs $\left(1.5 \times 10^{6}\right)$ or NAC (300 mg/ kg B.W.) at $24 \mathrm{~h}$ after APAP challenge. c Representative liver sections with TUNEL staining from control mice or APAP mice administered PBS, MSCs $\left(1.5 \times 10^{6}\right)$ or NAC $(300 \mathrm{mg} / \mathrm{kg}$ B.W.) at $24 \mathrm{~h}$ after APAP challenge. $\mathbf{d}$ Serum NAPQl levels analysed by ELISA in control mice or APAP mice administered PBS, MSCs $\left(1.5 \times 10^{6}\right)$ or NAC $(300 \mathrm{mg} / \mathrm{kg}$ B.W.) at $24 \mathrm{~h}$ after APAP challenge. e Flow cytometry analysis of the proportion of neutrophils and macrophages recruited to the liver from control mice or APAP mice administered PBS, MSCs $\left(1.5 \times 10^{6}\right)$ or NAC $(300 \mathrm{mg} / \mathrm{kg} \mathrm{B.W}$.) at $24 \mathrm{~h}$ after APAP challenge 
showed that although the administration of MSCs and NAC had similar attenuating effects on APAP-induced centrilobular necrosis, the administration of MSCs induced much fewer hepatocyte vacuolation than NAC (Fig. 2b). The extent of centrilobular hepatocyte necrosis and hepatocyte vacuolation was correlated with DNA fragmentation, as demonstrated by TUNEL analysis in Fig. 2c. The serum levels of major hepatocyte toxic metabolite, NAPQI, were increased after APAP administration when compared to control mice, while administration of both MSCs and NAC significantly reduced the serum levels of NAPQI, although the reduction level after MSC treatment was not as much as that after NAC treatment (Fig. 2d). In response to hepatocyte necrosis, the proportion of $\mathrm{CD}_{11} \mathrm{~b}^{+} \mathrm{Ly}_{6 \mathrm{G}}{ }^{+}$granulocytic myeloid-derived suppressor cells (MDSC), a type of immature neutrophils, recruited to the APAP-injured liver was increased compared to that of the control mice, and treatment with MSCs reduced the propor-

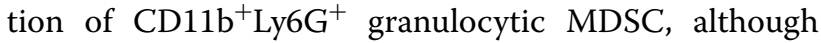
not as much as NAC treatment (Fig. 2e). However, MSC treatment enhanced the proportion of $\mathrm{CD} 11 \mathrm{~b}^{+} \mathrm{F} 4 / 80^{\mathrm{int}} /$ Ly- $6 \mathrm{C}^{+}$monocytic MDSC with restorative function [30], which was greater than that with NAC treatment (Fig. 2e), suggesting that MSCs recruit more monocytic MDSC to the liver than NAC does.

\section{MSCs are resistant to APAP-induced injury and protect hepatocytes from APAP-induced injury}

Since MSCs are live cells, the potential ability of APAP to induce MSC necrosis, less than the ability to induce hepatocyte necrosis, is important for their therapeutic efficacy. Different doses of APAP were used to treat MSCs and the human hepatocyte cell line L-O2. Compared to the untreated controls (0 mM APAP), APAP dose-dependently reduced the relative MTT activity of L-O2 cells by $32.9 \%$ and of MSCs by $84.8 \%$ at $20 \mathrm{mM}$ APAP (Fig. 3a). Flow cytometry analysis of apoptotic/ necrotic cells by Annexin V and 7-AAD revealed that APAP did not lower the proportion of surviving MSCs (Fig. 3b lower panel) but dose-dependently reduced that of L-O2 cells (Fig. 3b upper panel), suggesting that MSCs are more resistant to APAP injury than hepatocytes and that the reduction in cell viability based on MTT is due to growth inhibition rather than necrosis induction. When L-O2 cells were co-cultured with $1 \times 10^{6} \mathrm{MSCs}$ (Fig. 3c), the proportions of surviving L-O2 cells at different APAP doses were all higher than those of $\mathrm{L}-\mathrm{O} 2$ cells cultured alone (Fig. 3d), suggesting that MSCs can protect L-O2 cells from APAP-induced necrosis.
MSCs have similar survival-promoting effects to NAC

To compare MSCs to NAC, the optimal NAC dose to protect L-O2 cells from necrosis was analysed by MTT. As shown in Additional file 2, $6 \mathrm{mM}$ NAC showed the highest relative cell viability based on MTT in the presence of $20 \mathrm{mM}$ APAP. Therefore, $6 \mathrm{mM}$ NAC was used as the positive control NAC concentration to protect $\mathrm{L}-\mathrm{O} 2$ cells from APAP injury. In the presence of $20 \mathrm{mM}$ APAP, MSCs at $5 \times 10^{5}, 1 \times 10^{6}, 1.5 \times 10^{6}$ and $2 \times 10^{6}$ cells showed a dose-dependent tendency to increase the survival of L-O2 cells based on Giemsa staining (Fig. 4a), and flow cytometry analysis revealed that the survival proportion of L-O2 cells increased from 48.2 to $60.7 \%$ compared to that of non-co-cultured L-O2 cells (41.5\%) (Fig. 4b). More importantly, the survival proportion of L-O2 cells co-cultured with $2 \times 10^{6}$ MSCs was $60.7 \%$, which was comparable to $61.5 \%$ of the positive control, 6 mM NAC. Therefore, MSCs exerted survival-promoting effects on APAP-injured hepatocytes similar to those of NAC.

\section{MSCs attenuate APAP-induced necrosis of $\mathrm{L}-\mathrm{O} 2$ cells by secreting HGF}

It has been reported that MSCs regenerate or repair injured tissue or cells by producing trophic factors [21]. Among the trophic factors secreted by MSCs, HGF, EGF and IL- 6 are cytokines that affect hepatocyte survival and/or proliferation [21]. Intracellular staining and flow cytometry analysis showed that MSCs expressed HGF, IL-6 and EGF (Fig. 5a). There was a trend of dosedependent increases in HGF, EGF and IL-6 expression in the presence of APAP (Fig. 5b). When neutralizing antibodies were added to the co-culture system with $\mathrm{L}-\mathrm{O} 2$ cells and MSCs, the survival proportions of MSCs in the presence of HGF antibodies, EGF antibodies, IL-6 antibodies and IgG control antibodies were $42.7 \%$, 49.5\%, $49.5 \%$ and $52.9 \%$, respectively (Fig. $5 \mathrm{c}$, d). This suggests that all three kinds of antibodies blocked the survivalpromoting effects of MSCs on APAP-treated L-O2 cells to some extent, but the blocking effects of HGF antibodies were stronger than those of IL-6 antibodies or EGF antibodies (Fig. 5c, d). Therefore, HGF is the main cytokine secreted by MSCs that protects hepatocytes from APAP-induced necrosis.

\section{Knocking out HGF resulted in the failure of MSCs to rescue APAP-injured mice}

To confirm that HGF is an essential cytokine of MSCs to protect hepatocytes from APAP injury and rescue mice from APAP-induced liver failure, HGF was knocked out by CRISPR-Cas9 in MSCs. However, single clonal $\mathrm{HGF}^{\mathrm{ko}}$ MSCs were not successfully expanded in vitro, so we used MSCs after puromycin selection as 


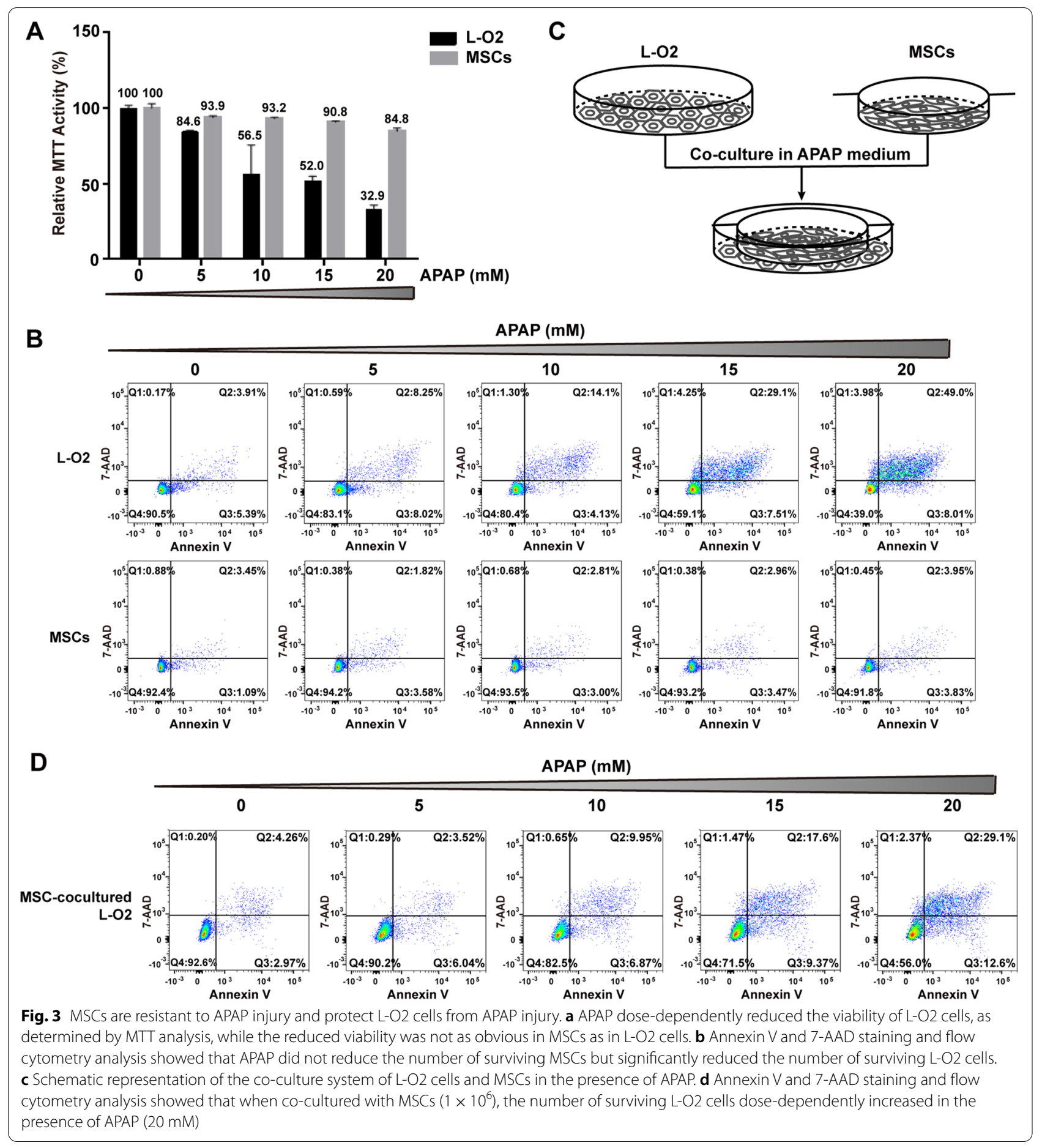

gRNA control MSCs and HGF ${ }^{\mathrm{ko}}$ MSCs. RT-PCR results showed that the transcription level of HGF was approximately half of that in the non-specific gRNA control cells (Fig. 6a), while the transcription level of EGF and IL- 6 was approximately 0.7 - and 1.4-fold, respectively, of that in the non-specific gRNA control cells
(Fig. 6a). When HGF-knockout MSCs were co-cultured with APAP-treated L-O2 cells, the survival proportion of L-O2 cells co-cultured with $\mathrm{HGF}^{\mathrm{ko}}$ MSCs was $47.3 \%$, which was much lower than the survival proportion of $69.7 \%$ for non-specific gRNA control cells (Fig. 6b, c), suggesting that knocking out HGF reduces 


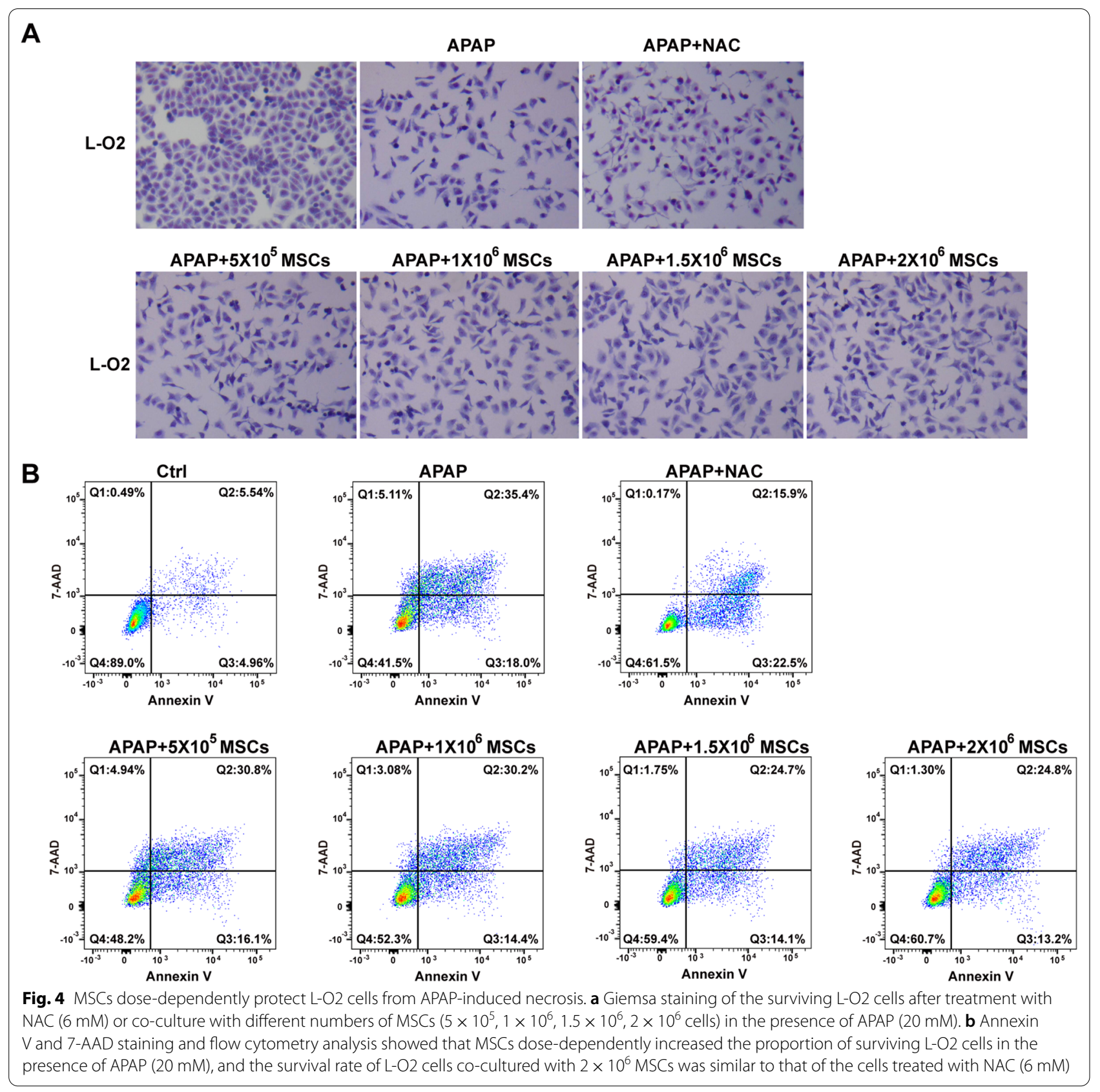

the protective effects of MSCs on APAP-induced cell necrosis. When transplanted into APAP-challenged mice (Fig. 6d), the survival proportion of APAP-challenged mice was $37.5 \%$ after the transplantation of $\mathrm{HGF}^{\mathrm{ko}}$ MSCs, which was significantly less than the survival proportion of $87.5 \%$ observed after the transplantation of non-specific gRNA control MSCs. As positive control, mouse HGF from 50 to $150 \mu \mathrm{g} / \mathrm{kg}$ B.W. rescued the mice from APAP-induced death dose-dependently with survival rate increase from 37.5 to $62.5 \%$, yet the survival rate of $\mathrm{HGF}(150 \mu \mathrm{g} / \mathrm{kg}$ B.W. $)$ administration was still lower than that of nc gRNA MSC transplantation (Fig. 6d). Therefore, these data suggest that HGF is the essential factor of MSCs that contributes to protecting hepatocytes from APAP-induced liver failure.

\section{Discussion}

Previous studies find the therapeutic effects of MSCs on APAP-induced liver failure [22-26] by inhibiting CYP2E1 activity [25], maintaining GSH levels [27] and increasing 

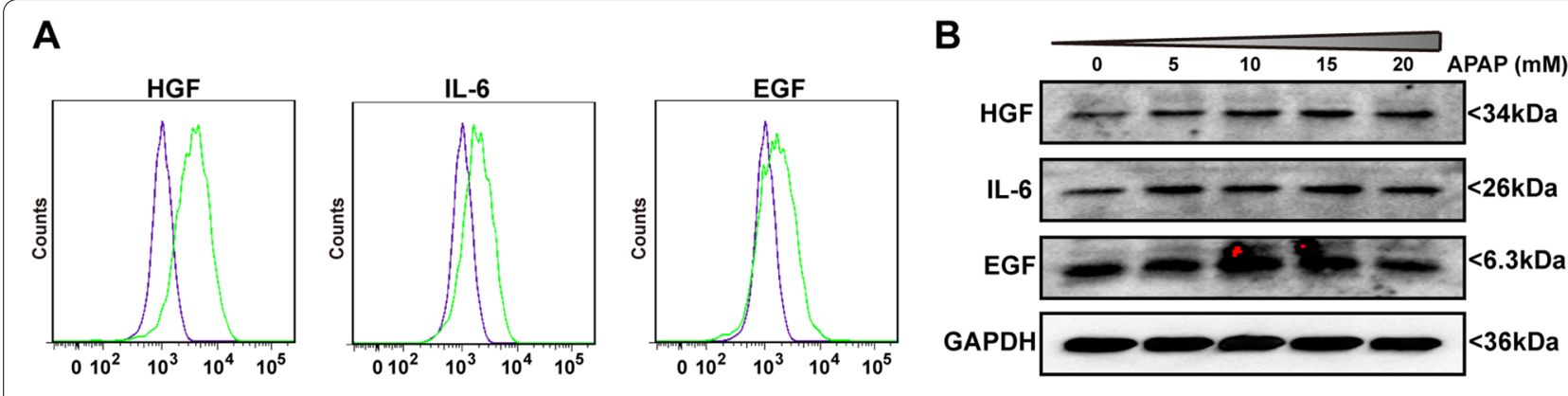

C

$20 \mathrm{mM}$ APAP
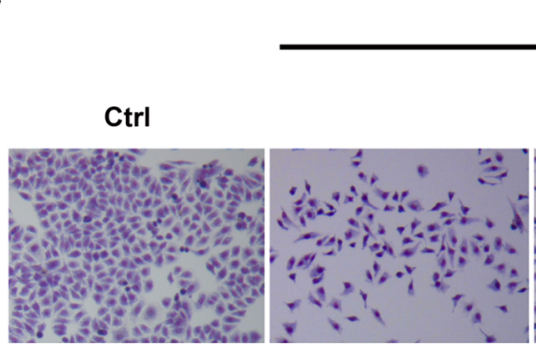

D
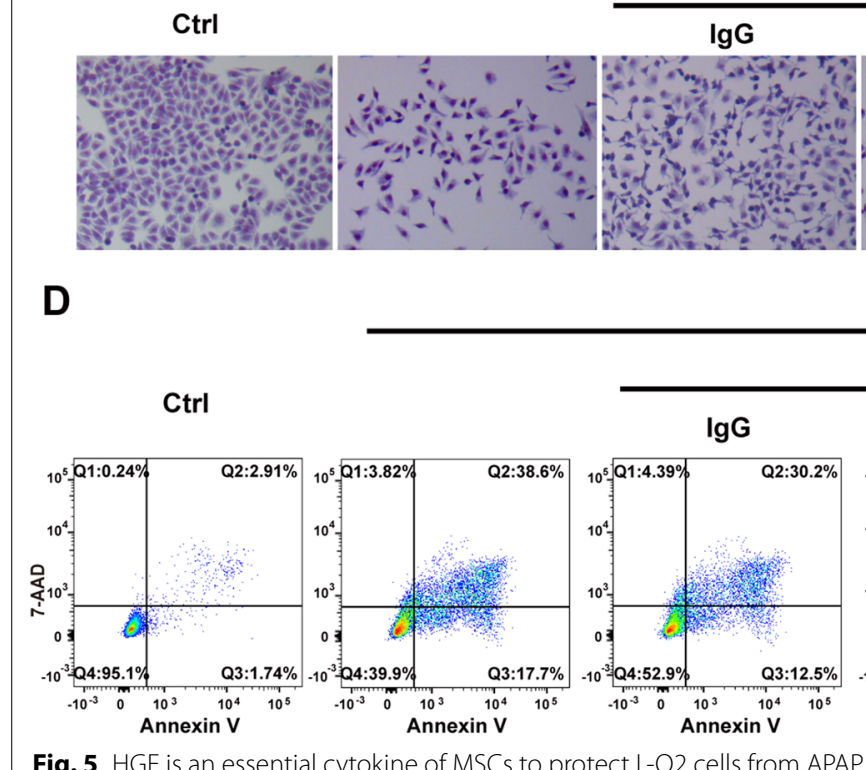

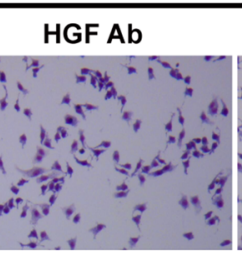

IL-6 Ab

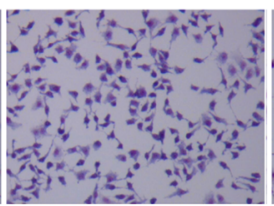

EGF Ab

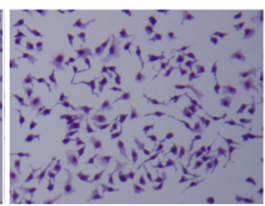

20mM APAP
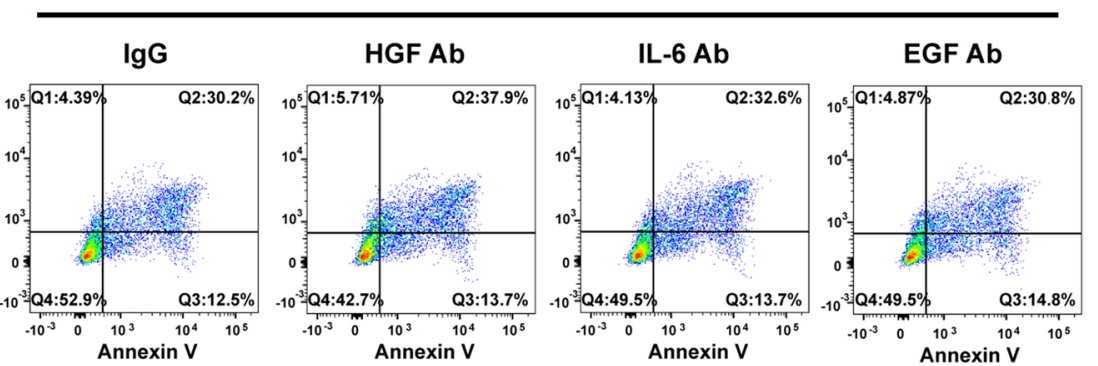

Fig. 5 HGF is an essential cytokine of MSCs to protect L-O2 cells from APAP injury. a Intracellular staining and flow cytometry analysis of HGF, IL-6 and EGF in MSCs. b Western blot analysis showed the sustained expression of HGF, IL-6 and EGF in APAP-treated MSCs. c Giemsa staining of the surviving L-O2 cells co-cultured with MSCs and neutralizing antibodies against HGF, IL-6 and EGF in the presence of APAP (20 mM). d Annexin V and 7-AAD staining and flow cytometry analysis showed that HGF neutralization antibodies blocked the anti-necrotic effects of MSCs on APAP-treated L-O2 cells compared to IL-6 or EGF neutralization antibodies

\section{(See figure on next page.)}

Fig. 6 Knockout of HGF abrogates the anti-necrosis effects and therapeutic effects of MSCs on APAP-induced L-O2 cell injury and mouse liver failure. a Knockout of HGF by CRISPR-Cas9 reduced HGF transcription. b Giemsa staining of the surviving L-O2 cells co-cultured with HGF ${ }^{\mathrm{ko}}$ MSCS and non-specific gRNA control MSCs. c Annexin V and 7-AAD staining and flow cytometry analysis showed that the knockout of HGF reduced the anti-necrosis effects of MSCs on APAP-treated L-O2 cells compared to non-specific gRNA control MSCs. $\mathbf{d}$ Seven-day survival curve after APAP ( 500 mg/kg B.W.)-induced liver failure mice were treated with PBS or HGF ${ }^{\mathrm{ko}}$ MSCs $\left(1 \times 10^{6}\right)$ or non-specific gRNA control MSCs $\left(1 \times 10^{6}\right)$ or different concentrations of HGF $(50 \mathrm{mg} / \mathrm{kg}$ B.W., $100 \mathrm{mg} / \mathrm{kg} \mathrm{B.W.} \mathrm{and} 150 \mathrm{mg} / \mathrm{kg}$ B.W.)

antioxidant enzyme activity [28]. Compared to previous studies, there are two novelties of this study. One is that the efficacy of MSC administration to treat APAP injury is similar to that of the clinical used drug, NAC and MSCs induce less hepatocyte vacuolation than NAC. The other is that HGF, a hepatocyte growth stimulatory cytokine, is the major cytokine by which MSCs protect hepatocytes from APAP injury and rescue mice from APAP-induced liver failure. Therefore, administration of MSCs may overcome the problems of regeneration retardation and hepatocyte vacuolation after prolonged NAC treatment, thus serving as a new therapeutic option for APAP overdose poisoning. 

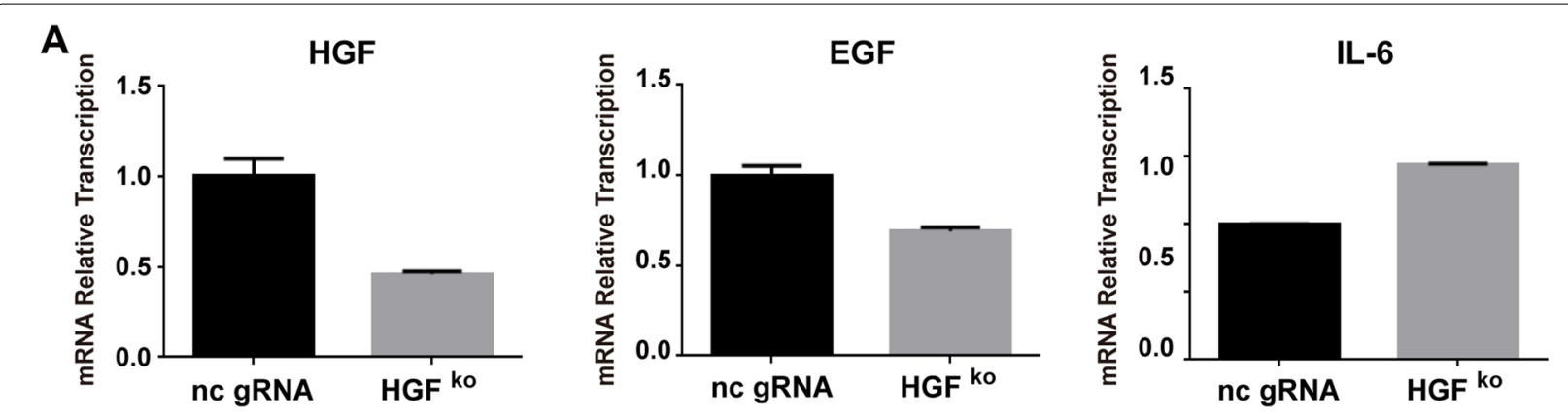

B
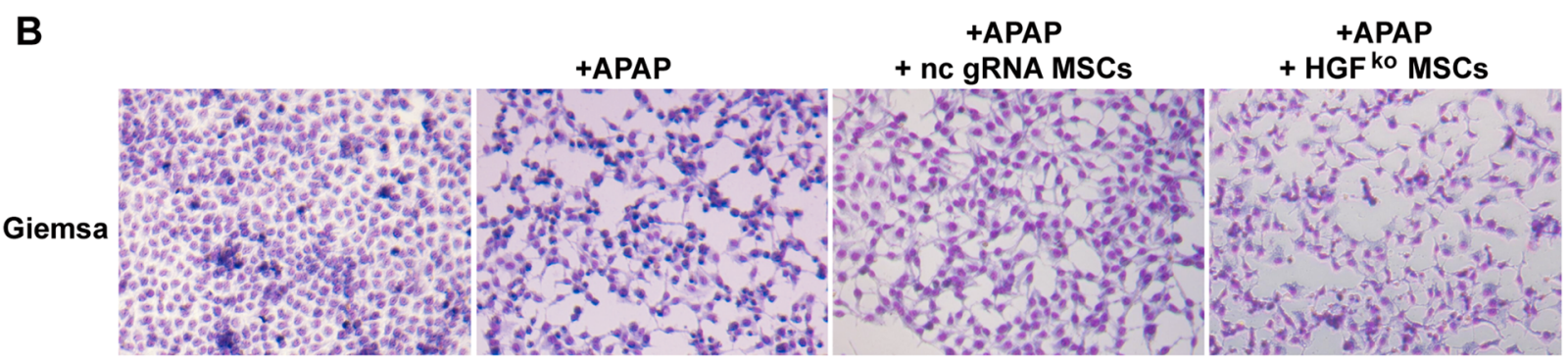

C
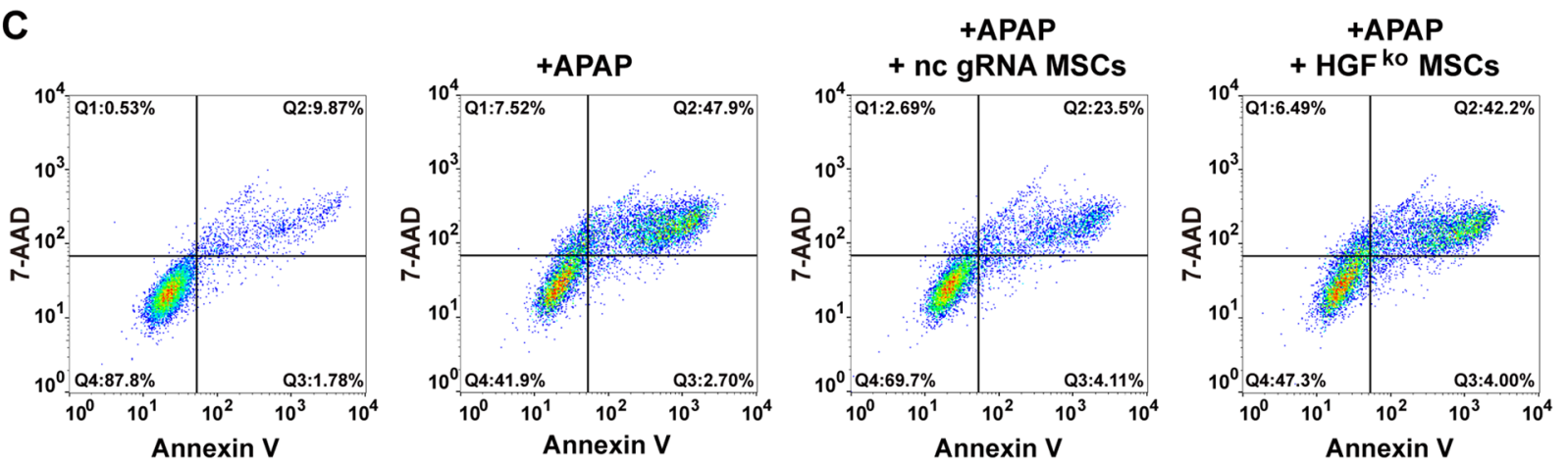

D

nc gRNA MSCs or HGF ${ }^{\text {ko }}$ MSCs

$500 \mathrm{mg} / \mathrm{kg} \mathrm{B.W}$. or HGF injection

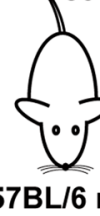

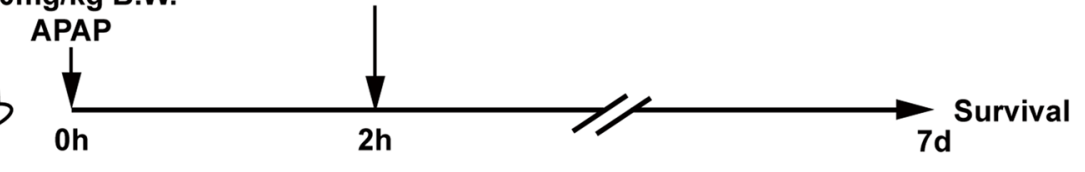

C57BL/6 mice

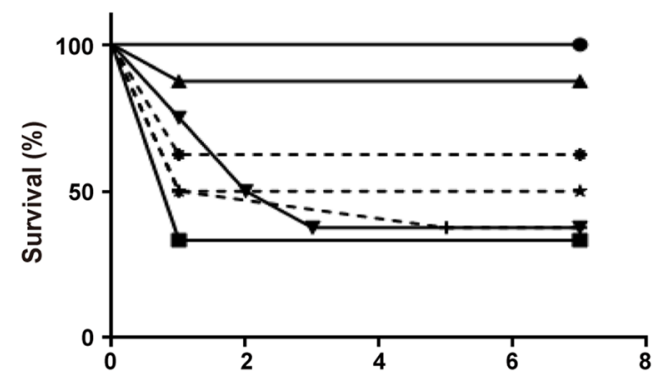

$\rightarrow$ Ctrl: $100 \%(\mathrm{~N}=4)$

- APAP: $33.3 \%(\mathrm{~N}=9)$

- APAP $+1 \times 10^{6}$ nc gRNA MSCs : $87.5 \%(\mathrm{~N}=8)$

- APAP+1 $10^{6}{ }^{6} \mathrm{HGF}^{\mathrm{ko}} \mathrm{MSCs}: 37.5 \%(\mathrm{~N}=8)$

-+. APAP $+50 \mathrm{\mu g} / \mathrm{kg}$ B.W. HGF: $37.5 \%(\mathrm{~N}=8)$

- * APAP $+100 \mu \mathrm{g} / \mathrm{kg}$ B.W. HGF: $50.0 \%(\mathrm{~N}=8)$

- APAP+150 $\mu \mathrm{g} / \mathrm{kg}$ B.W. HGF: $62.5 \%(\mathrm{~N}=8)$

Fig. 6 (See legend on previous page.) (Days) 
For translational consideration, we select human MSCs developed according to GMP guidelines to treat mouse liver injury for obtaining preclinical data of human MSCs as a drug for future clinical research. It has been found that xenotransplantation of human MSCs show therapeutic effects on APAP-induced mouse liver failure [28, 31]. Furthermore, cultured human MSCs only express low levels of MHC class I and do not express MHC class II or co-stimulatory molecules, including B7-1, B-72 and CD40 [32-34], which results in low immunogenicity of MSCs and makes them eligible for allogeneic transplantation [35]. There may be immunological effects in this xenogeneic cell therapy, but if we could get therapeutic effects under these host immunological rejection condition, we could expect a more effective therapeutic outcome during allotransplantation.

There are two essential aspects for evaluating the efficacy of new therapeutic candidates at the preclinical stage: dose-dependent therapeutic effects to treat diseases and at least comparable therapeutic effects to clinically used drugs. For dose-dependent effects, we found that L-O2 cells co-cultured with different numbers of MSCs showed a dose-dependent increase in the proportion of surviving cells in the presence of APAP, confirming the protective effects of MSCs against APAP-induced L-O2 cell necrosis. More importantly, human umbilical cord MSCs (from $1 \times 10^{5}$ to $5 \times 10^{5}$ cells) in APAP mice dose-dependently increased the survival rate of $750 \mathrm{mg} /$ $\mathrm{kg}$ B.W. APAP-challenged BALB/c mice, and no further increase was observed in mice transplanted with $1 \times 10^{6}$ MSCs [28]. Similarly, we found dose-dependent therapeutic effects of MSCs (from $5 \times 10^{5}$ to $1 \times 10^{6}$ cells) on $500 \mathrm{mg} / \mathrm{kg} \mathrm{B.W.} \mathrm{APAP-challenged} \mathrm{C57BL/6J} \mathrm{mice,} \mathrm{and}$ no further increase was observed in mice transplanted with $1.5 \times 10^{6}$ or $2.0 \times 10^{6}$ MSCs. Although different mouse subtypes and different APAP doses were used for liver failure induction, both studies observed the dosedependent therapeutic effects of human MSCs on APAPinduced mouse liver failure.

As an antidote recommended for APAP overdose therapy, NAC has been confirmed to be effective in animal models [20,36] and clinical trials [6, 7]. Clinically, intravenous NAC administration improves patients with fulminant hepatic failure after paracetamol overdose from $20 \%(N=25)$ to $48 \%(N=48)$ with three regimens of $150 \mathrm{mg}, 50 \mathrm{mg}$ and $100 \mathrm{mg}$ per $\mathrm{kg}$ B.W. NAC in $5 \%$ dextrose over $15 \mathrm{~min}, 4 \mathrm{~h}$ and over $16 \mathrm{~h}$, with approximately $30 \%$ more patients surviving [6]. Human umbilical cord-derived MSCs $\left(5 \times 10^{5}\right)$ increased the survival proportion of $750 \mathrm{mg} / \mathrm{kg}$ B.W. APAP-challenged mice from 0 to $40 \%$ [28], mouse omentum adipose-derived MSCs $\left(1 \times 10^{6}\right)$ rescued the survival of $600 \mathrm{mg} / \mathrm{kg}$ B.W. APAPchallenged mice from 60 to $90 \%$ [25], and our human umbilical cord-derived MSCs $\left(1 \times 10^{6}\right)$ rescued survival levels from 37.5 to $87.5 \%$ for $600 \mathrm{mg} / \mathrm{kg}$ B.W. APAPchallenged mice, which suggests a $30-40 \%$ increase in the rescue effects of human MSCs on mouse APAP-induced liver failure. In comparison to NAC, we found that the rescue survival level $87.5 \%$ of $1 \times 10^{6}$ MSCs were similar to $90.0 \%$ of NAC after administration to the mice at $2 \mathrm{~h}$ after APAP injection. Our in vitro studies also confirmed the similar survival-promoting effects of $2 \times 10^{6} \mathrm{MSCs}$ to the optimized NAC dose on APAP-treated L-O2 cells. Although the ALT and AST levels of mice treated with $1 \times 10^{6}$ MSCs were higher than those of NAC-treated mice, the ALT and AST levels of mice administered $1.5 \times 10^{6}$ or $2 \times 10^{6}$ MSCs were not significantly different from those of NAC-treated mice. These data further confirm the dose-dependent effects of MSCs and suggest the urgent need to optimize the therapeutic dose of MSCs for APAP-induced liver failure. Therefore, MSCs fulfil the criteria of a new candidate for treating APAP-induced liver failure with dose-dependent therapeutic effects and comparable effects to the clinically used drug NAC.

Hepatocyte vacuolation to delay liver recovery is the major obstacle for NAC prolonged clinical usage to treat APAP-liver failure [13]. In contrast to NAC, MSCs mainly exert therapeutic effects by secreting cytokines to promote hepatocyte proliferation and prevent apoptosis [21]. Among these cytokines, HGF has been revealed to be increased in the serum of MSC-treated APAP-challenged mice [28]. We found that among the three major hepatocyte survival/growth stimulating factors secreted by MSCs, HGF had more anti-necrosis effects on APAPtreated L-O2 cells than EGF or IL-6. More importantly, the rescue effects of HGF-knockout MSCs on the survival of APAP-challenged mice decreased to half of the level of control MSCs, further confirming the essential function of HGF in the therapeutic effects of MSCs. Since HGF-knockout MSC clones were not successfully expanded in vitro, HGF may be an important cytokine that supports the growth of MSCs. Considering that the mechanism through which MSCs affect APAP-induced liver failure involves secreting HGF to rescue hepatocytes from death and promote their proliferation, transplanting MSCs may avoid hepatocyte vacuolation and impeded liver regeneration after prolonged NAC treatment, serving as an additional candidate for APAP overdose patients.

We understand that safety is the most important aspect of drug development, and we noticed that some mice died immediately after the administration of MSCs in a dose-dependent manner. There may be two explanations for this severe adverse event. One is that the MSCs used in these experiments were isolated from humans, and human cells are twice the size of mouse 
cells [37], thus increasing the risk for pulmonary infarction. The other is that since MSCs were resuspended in $100 \mathrm{ml} \mathrm{PBS}$ at the desired concentration for tail vein transplantation, as the cell number used for transplantation increased, the concentration of cell suspension administered to the mice in a very short period of time also increased. For clinical usage, the transplantation of human MSCs to treat human diseases and the intravenous infusion of MSCs at lower cell concentrations and over a relatively long time period may reduce the risk for pulmonary infarction, and many clinical trials have confirmed no critical infusion-related effects of transplanting allogenic MSCs for HBV-related acuteon-chronic liver failure [38] and liver cirrhosis [39]. Therefore, transplanting human allogenic MSCs to humans may not lead to the severe adverse events that were observed in mice.

\section{Conclusions}

In summary, MSCs exert anti-necrosis effects on APAPinjured hepatocytes to increase the survival of APAPchallenged mouse liver failure by secreting HGF, and the efficacy of transplanting MSCs is similar to those of the clinically used drug NAC. Since HGF is a growth stimulatory cytokine for hepatocytes, administration of MSCs may overcome the regeneration retardation and hepatocyte vacuolation effects of NAC after prolonged treatment, thus serving as a new therapeutic candidate for future clinical use of APAP overdose.

\section{Abbreviations}

NAC: N-Acetylcysteine; APAP: Acetaminophen; NAPQI: N-Acetyl-p-benzoquinone imine; GSH: Glutathione; MSCs: Mesenchymal stem cells (MSCs); HGF: Hepatocyte growth factor; EGF: Epidermal growth factor; IL-6: Interleukin-6.

\section{Supplementary Information}

The online version contains supplementary material available at https://doi. org/10.1186/s13287-022-02754-X.

Additional file 1: Optimize the dose of APAP for liver failure and the dose of NAC for treating APAP-induced liver failure. A Schematic representation of the experiment design and seven-day survival curve to determine the dosage for APAP-induced liver failure in mice. B Schematic representation of the experiment design and seven-day survival curve to optimize the NAC dosage to treat APAP-induced liver failure in mice.

Additional file 2: MTT analysis to optimize the NAC dose for blocking APAP-induced $\mathrm{L}-\mathrm{O} 2$ cell necrosis.

\section{Acknowledgements}

We thank the Clinical Data and Biobank Resource of Beijing Friendship Hospital for storing the liver samples.

\section{Authors' contributions}

PW, YC, DC, HY and JJ conceived the study and the experimental design and supervised the study. JW and DL prepared and cultured MSCs for animal experiments. YC, YT, KL, XW, LL, YH, YP and LL performed experiments and acquired the data. PW, LS, ZZ, HY and JJ wrote and edited the manuscript. All authors read and approved the final manuscript.

\section{Funding}

This work was supported by the National Natural Science Foundation of China (81570548 and 81770598) and the National Science and Technology Major Special Project for New Drug Development (2018ZX09201016).

\section{Availability of data and materials}

The datasets used and/or analysed in this study are available from the corresponding author on reasonable request.

\section{Declarations}

Ethical approval and consent to participate.

All experiments using MSCs were approved by the Ethical Committees of ASIS Hospital Beijing, China (No. LLPJ2017[001], with informed consent from the donor. The Animal Care and Use Committee of Beijing Friendship Hospital, Capital Medical University approved all animal experiments (No. 19-2010).

\section{Consent for publication}

Not applicable.

\section{Competing interests}

The authors declare that they have no competing interests.

\section{Author details}

${ }^{1}$ Liver Research Center, Beijing Friendship Hospital, Capital Medical University, Beijing Key Laboratory of Translational Medicine on Liver Cirrhosis and National Clinical Research Center for Digestive Diseases, No. 95 Yong-An Road, Beijing 100050, China. ${ }^{2}$ BOE Regenerative Medicine Technology Co., Ltd., Beijing 100015, China. ${ }^{3}$ Experimental and Translational Research Center, Beijing Friendship Hospital, Capital Medical University, Beijing Key Laboratory of Tolerance Induction and Organ Protection in Transplantation and National Clinical Research Center for Digestive Diseases, Beijing 100050, China. ${ }^{4}$ Division of Liver Transplantation Surgery, Department of Surgery, Beijing Friendship Hospital, Capital Medical University and National Clinical Research Center for Digestive Diseases, Beijing 100050, China. ${ }^{5}$ Department of Cell Therapy in Regenerative Medicine, University of Tokyo Hospital, Tokyo 113-8655, Japan.

Received: 7 September 2021 Accepted: 26 October 2021

Published online: 04 March 2022

References

1. Rapposelli D. Highlights from AASLD 2013. Gastroenterol Hepatol (N Y). 2013;9:833-4

2. Antoine DJ, Dear JW. How to treat paracetamol overdose and when to do it. Expert Rev Clin Pharmacol. 2016;9:633-5. https://doi.org/10.1586/ 17512433.2016 .1154786$.

3. Lee WM. Acetaminophen and the U.S. Acute Liver Failure Study Group: lowering the risks of hepatic failure. Hepatology. 2004;40:6-9. https://doi. org/10.1002/hep.20293.

4. Lee WM. Acetaminophen (APAP) hepatotoxicity-Isn't it time for APAP to go away? J Hepatol. 2017;67:1324-31. https://doi.org/10.1016/j.jhep.2017. 07.005.

5. Bernal W, Auzinger G, Dhawan A, Wendon J. Acute liver failure. Lancet. 2010;376:190-201. https://doi.org/10.1016/S0140-6736(10)60274-7.

6. Keays R, Harrison PM, Wendon JA, Forbes A, Gove C, Alexander GJ, Williams R. Intravenous acetylcysteine in paracetamol induced fulminant hepatic failure: a prospective controlled trial. BMJ. 1991;303:1026-9. https://doi.org/10.1136/bmj.303.6809.1026.

7. Smilkstein MJ, Knapp GL, Kulig KW, Rumack BH. Efficacy of oral N-acetylcysteine in the treatment of acetaminophen overdose. Analysis of the national multicenter study (1976 to 1985). N Engl J Med. 1988;319:155762. https://doi.org/10.1056/NEJM198812153192401. 
8. Polson J, Lee WM. American Association for the Study of Liver D. AASLD position paper: the management of acute liver failure. Hepatology. 2005;41:1179-97. https://doi.org/10.1002/hep.20703.

9. Jaeschke H, Akakpo JY, Umbaugh DS, Ramachandran A. Novel therapeutic approaches against acetaminophen-induced liver injury and acute liver failure. Toxicol Sci. 2020;174:159-67. https://doi.org/10.1093/toxsci/ kfaa002.

10. Chiew AL, Gluud C, Brok J, Buckley NA. Interventions for paracetamol (acetaminophen) overdose. Cochrane Database Syst Rev. 2018;2:CD003328. https://doi.org/10.1002/14651858.CD003328.pub3.

11. Whyte IM, Francis B, Dawson AH. Safety and efficacy of intravenous $\mathrm{N}$-acetylcysteine for acetaminophen overdose: analysis of the Hunter Area Toxicology Service (HATS) database. Curr Med Res Opin. 2007;23:2359-68. https://doi.org/10.1185/030079907X219715.

12. Kerr F, Dawson A, Whyte IM, Buckley N, Murray L, Graudins A, Chan B, Trudinger B. The Australasian Clinical Toxicology Investigators Collaboration randomized trial of different loading infusion rates of $\mathrm{N}$-acetylcysteine. Ann Emerg Med. 2005;45:402-8. https://doi.org/10.1016/j. annemergmed.2004.08.040.

13. Yang R, Miki K, He X, Killeen ME, Fink MP. Prolonged treatment with $\mathrm{N}$-acetylcystine delays liver recovery from acetaminophen hepatotoxicity. Crit Care. 2009;13:R55. https://doi.org/10.1186/cc7782.

14. Pakravan N, Waring WS, Sharma S, Ludlam C, Megson I, Bateman DN. Risk factors and mechanisms of anaphylactoid reactions to acetylcysteine in acetaminophen overdose. Clin Toxicol (Phila). 2008;46:697-702. https:// doi.org/10.1080/15563650802245497.

15. Sandilands EA, Bateman DN. Adverse reactions associated with acetylcysteine. Clin Toxicol (Phila). 2009;47:81-8. https://doi.org/10.1080/15563 650802665587.

16. Jaeschke H, Ramachandran A. Acetaminophen-induced apoptosis: facts versus fiction. J Clin Transl Res. 2020;6:36-47.

17. Chowdhury A, Nabila J, Adelusi Temitope I, Wang S. Current etiological comprehension and therapeutic targets of acetaminophen-induced hepatotoxicity. Pharmacol Res. 2020;161:105102. https://doi.org/10. 1016/j.phrs.2020.105102.

18. Ramachandran A, Jaeschke H. Acetaminophen hepatotoxicity: A mitochondrial perspective. Adv Pharmacol. 2019;85:195-219. https://doi.org/ 10.1016/bs.apha.2019.01.007.

19. McGill MR, Sharpe MR, Williams CD, Taha M, Curry SC, Jaeschke H. The mechanism underlying acetaminophen-induced hepatotoxicity in humans and mice involves mitochondrial damage and nuclear DNA fragmentation. J Clin Invest. 2012;122:1574-83. https://doi.org/10.1172/ JCI59755.

20. Saito C, Zwingmann C, Jaeschke H. Novel mechanisms of protection against acetaminophen hepatotoxicity in mice by glutathione and N-acetylcysteine. Hepatology. 2010;51:246-54. https://doi.org/10.1002/ hep.23267.

21. Lee CW, Chen YF, Wu HH, Lee OK. Historical perspectives and advances in mesenchymal stem cell research for the treatment of liver diseases. Gastroenterology. 2018;154:46-56. https://doi.org/10.1053/j.gastro.2017. 09.049.

22. Banas A, Teratani T, Yamamoto Y, Tokuhara M, Takeshita F, Osaki M, Kawamata M, Kato T, Okochi H, Ochiya T. IFATS collection: in vivo therapeutic potential of human adipose tissue mesenchymal stem cells after transplantation into mice with liver injury. Stem Cells. 2008;26:2705-12. https://doi.org/10.1634/stemcells.2008-0034.

23. Cao H, Yang J, Yu J, Pan Q, Li J, Zhou P, Li Y, Pan X, Li J, Wang Y, Li L. Therapeutic potential of transplanted placental mesenchymal stem cells in treating Chinese miniature pigs with acute liver failure. BMC Med. 2012;10:56. https://doi.org/10.1186/1741-7015-10-56.

24. de Freitas Souza BS, Nascimento RC, de Oliveira SA, Vasconcelos JF, Kaneto CM, de Carvalho LF, Ribeiro-Dos-Santos R, Soares MB, de Freitas $L A$. Transplantation of bone marrow cells decreases tumor necrosis factor-alpha production and blood-brain barrier permeability and improves survival in a mouse model of acetaminophen-induced acute liver disease Cytotherapy. 2012;14:1011-21. https://doi.org/10.3109/14653249.2012. 684445.

25. Huang YJ, Chen P, Lee CY, Yang SY, Lin MT, Lee HS, Wu YM. Protection against acetaminophen-induced acute liver failure by omentum adipose tissue derived stem cells through the mediation of Nrf2 and cytochrome
P450 expression. J Biomed Sci. 2016;23:5. https://doi.org/10.1186/ s12929-016-0231-x.

26. Hu C, Zhao L, Wu Z, Li L. Transplantation of mesenchymal stem cells and their derivatives effectively promotes liver regeneration to attenuate acetaminophen-induced liver injury. Stem Cell Res Ther. 2020;11:88. https://doi.org/10.1186/s13287-020-01596-9.

27. Salomone F, Barbagallo I, Puzzo L, Piazza C, Li VG. Efficacy of adipose tissue-mesenchymal stem cell transplantation in rats with acetaminophen liver injury. Stem Cell Res. 2013;11:1037-44. https://doi.org/10. 1016/j.scr.2013.07.003.

28. Liu Z, Meng F, Li C, Zhou X, Zeng X, He Y, Mrsny RJ, Liu M, Hu X, Hu JF, Li T. Human umbilical cord mesenchymal stromal cells rescue mice from acetaminophen-induced acute liver failure. Cytotherapy. 2014;16:120719. https://doi.org/10.1016/j.jcyt.2014.05.018.

29. Wang P, Cong M, Liu TH, Yang AT, Cong R, Wu P, Tang SZ, Xu Y, Wang H, Wang BE, Jia JD, You H. Primary isolated hepatic oval cells maintain progenitor cell phenotypes after two-year prolonged cultivation. J Hepatol. 2010;53:863-71. https://doi.org/10.1016/j.jhep.2010.05.014.

30. Ramachandran P, Pellicoro A, Vernon MA, Boulter L, Aucott RL, Ali A, Hartland SN, Snowdon VK, Cappon A, Gordon-Walker TT, Williams MJ, Dunbar DR, Manning JR, van Rooijen N, Fallowfield JA, Forbes SJ, Iredale JP. Differential Ly-6C expression identifies the recruited macrophage phenotype, which orchestrates the regression of murine liver fibrosis. Proc Natl Acad Sci U S A. 2012;109:E3186-95. https://doi.org/10.1073/pnas.1119964109.

31. Hua D, Ju Z, Gan X, Wang Q, Luo C, Gu J, Yu Y. Human amniotic mesenchymal stromal cells alleviate acute liver injury by inhibiting the proinflammatory response of liver resident macrophage through autophagy. Ann Transl Med. 2019;7:392. https://doi.org/10.21037/atm.2019.08.83.

32. Tse WT, Pendleton JD, Beyer WM, Egalka MC, Guinan EC. Suppression of allogeneic T-cell proliferation by human marrow stromal cells: implications in transplantation. Transplantation. 2003;75:389-97. https://doi.org/ 10.1097/01.TP.0000045055.63901.A9.

33. Le Blanc K, Tammik C, Rosendahl K, Zetterberg E, Ringden O. HLA expression and immunologic properties of differentiated and undifferentiated mesenchymal stem cells. Exp Hematol. 2003;31:890-6. https://doi.org/10. 1016/s0301-472x(03)00110-3.

34. Le Blanc K, Tammik L, Sundberg B, Haynesworth SE, Ringden O. Mesenchymal stem cells inhibit and stimulate mixed lymphocyte cultures and mitogenic responses independently of the major histocompatibility complex. Scand J Immunol. 2003;57:11-20. https://doi.org/10.1046/j. 1365-3083.2003.01176.x.

35. Fan XL, Zhang $Y$, Li X, Fu QL. Mechanisms underlying the protective effects of mesenchymal stem cell-based therapy. Cell Mol Life Sci. 2020;77:2771-94. https://doi.org/10.1007/s00018-020-03454-6.

36. James LP, McCullough SS, Lamps LW, Hinson JA. Effect of N-acetylcysteine on acetaminophen toxicity in mice: relationship to reactive nitrogen and cytokine formation. Toxicol Sci. 2003;75:458-67. https://doi.org/10.1093/ toxsci/kfg181.

37. Miller MW, Battaglia LF. The relevance of cell size on ultrasound-induced hemolysis in mouse and human blood in vitro. Ultrasound Med Biol. 2003;29:1479-85. https://doi.org/10.1016/s0301-5629(03)00966-9.

38. Lin BL, Chen JF, Qiu WH, Wang KW, Xie DY, Chen XY, Liu QL, Peng L, Li $J G$, Mei YY, Weng WZ, Peng YW, Cao HJ, Xie JQ, Xie SB, Xiang AP, Gao ZL. Allogeneic bone marrow-derived mesenchymal stromal cells for hepatitis $B$ virus-related acute-on-chronic liver failure: A randomized controlled trial. Hepatology. 2017;66:209-19. https://doi.org/10.1002/hep.29189.

39. Kharaziha P, Hellstrom PM, Noorinayer B, Farzaneh F, Aghajani K, Jafari F, Telkabadi M, Atashi A, Honardoost M, Zali MR, Soleimani M. Improvement of liver function in liver cirrhosis patients after autologous mesenchymal stem cell injection: a phase I-II clinical trial. Eur J Gastroenterol Hepatol. 2009;21:1199-205. https://doi.org/10.1097/MEG.0b013e32832a1f6c.

\section{Publisher's Note}

Springer Nature remains neutral with regard to jurisdictional claims in published maps and institutional affiliations. 